\title{
Franchise Focus Choices
}

\section{Focusing on a Customer Franchise}

The concept of a customer franchise is relatively new to the marketing field and refers to the hold a company has on a given industrial user group. The group needs to be clearly defined and is best described as a group of professionals, or businesses, who perform a singular function. For a franchise to be effective, the products or services need to be crucial to the execution of the business activities of the industrial user group, the professionals, or other businesses. This is about the products that are really central to the business, not about a legal relationship.

This type of customer franchise concept is not to be confused with a consumer brand franchise often used in a business-to-consumer (B2C) marketing environment. That version of the franchise will be addressed later in the book. In this research, several companies were discovered to focus on customer franchises-supplying these businesses, or companies, with key equipment, components, or products.

\section{Building a Customer Franchise Around Industries}

Komax, serves as an example of the approach of building a customer franchise by targeting companies involved in cabling, or wire harnesses, used in a number of industries. Gradually, the Komax equipment for creating wire harnesses became central and essential to wiring firms supplying original equipment manufacturers (OEMs) with pre-manufactured wiring for easy and quick installation in assembly operations that had previously been done manually. As a result, a new group of companies_-wire harness manufacturers—emerged.

Although the first Komax equipment was intended for a range of application segments, it was the automotive industry that emerged early on as a major user of Komax equipment. Wiring a car efficiently and to a highquality standard had always been a challenge. Automotive OEMs increasingly moved this capability to wire harness manufacturers who 
assumed the role of Tier One suppliers. A compact car 'consumed' about 1300 wires, of which 25 percent were twisted, for a total length of 2000 meters. There were about 250 plug housings to connect and about $2300 \mathrm{crimp}$ contacts. Weighing more than $30 \mathrm{~kg}$, the harness cost about CHF 400 to produce. For a full-sized car, the numbers were about 50 percent to almost twice that.

The megatrends in the automotive industry contributed to a growth of wiring. Additional safety features required more sensors to connect. The growing 'electrification' of automobiles contributed to a marked increase in cabling per vehicle. Increasing complexity and ever more power supply systems required more automation and thus, more cabling. The increasing quality standards demanded more automated solutions. All of this tended to increase the market for automated wire processing and equipment, such as the ones produced by Komax. Given what wire processing machinery could do for the manufacturers of wire harnesses, it was no surprise that harness manufacturers for the automotive industry were the largest customer group of Komax. ${ }^{1}$

Once Komax had established a firm position for its cabling equipment, the company began to expand its role with cablers by continuously enhancing its services, moving along the cablers' internal activity cycle. This expansion was executed through a series of acquisitions that brought additional equipment providers in-house.

Komax' strategy of focusing on wire processing systems came with an expanded scrutiny of its industry that created many growth opportunities. The company analyzed the entire wire harnessing production cycle and the time spent on each step. While important from an efficiency point of view, cutting, stripping and crimping, the core activities of Komax systems, accounted for only 20 percent of the time needed to create a wire harness in the automotive industry. Routing and pre-assembly / taping accounted for 28 and 25 percent, respectively.

New insights came from investigating the entire value chain of its customers, going beyond what had been the focus of the initial wire processing systems. The strategy was now clear that Komax wanted to expand the 'share of wallet' of its main customers and enter other value chain steps previously left to other companies. Between 2013 and 2017, Komax grew its wire processing business from CHF 254 mio to CHF 409 mio, with more than 80 percent originating from the automotive sector alone. ${ }^{2}$

\section{Building a Customer Franchise Around Institutions}

Thermoplan, with its automated coffee machines geared for the hospitality industry, pursued its own version of building a customer franchise among coffee chains, restauranteurs, and institutions.

From inception, Thermoplan was following a business-to-business (B2B) model supplying professional kitchens, restaurants and hotels. This model was maintained, and the bulk of its equipment went into professional use, setting the company apart from other espresso machine suppliers, such as Jura, another Swiss company focusing on espresso machines

\footnotetext{
${ }^{1}$ Adapted from Komax company profile.

${ }^{2}$ Adapted from Komax company profile.
} 
for in-home use. With Thermoplan's two main lines designed for either a 150 cups per day or 500 cups per day environment, the company clearly had professional users in mind. Today, about 50 percent of Thermoplan sales were to customers purchasing dedicated custom-made coffee machines. The Starbucks volume was put at 30 percent of sales. The other half of company sales were made with its standard Black \& White Model Range, now in its 4th generation, distributed to hotels and restaurants in a B2B environment. ${ }^{3}$

For companies pursuing the focus on a given customer franchise, a broad product line is necessary to provide an enlarged service. The analysis of a customer's activity cycle, whereby each step in the manufacturing process is analyzed to probe for an enlarged footprint, offers insights into ways to become increasingly important and, thus, indispensable to the customer. LNS also moved along this path to enlarge its business for bar feeders. ${ }^{4}$

By the late 1990s, LNS had developed the largest global sales network for bar feeders. With margins declining due to emerging competition, the company began to think about ways to monetize its large sales force by piggybacking on related products. At this time, Turbo Systems Inc., a US-based company selling chip management systems to the same customer base using LNS bar feeders, approached LNS. Chip management systems were also engineered into the OEM machines and automatically collected the chips created from machining the metal bars. The US company had about the same amount of sales as LNS but did not have its own sales force.

Integrating Turbo Systems chip collectors with the LNS sales force proved to be a major challenge and required quite a bit of re-engineering as chip collectors were more difficult to adapt to various CNC machines, a necessary step for LNS to take those products global. It took about five years until the LNS sales force was comfortable selling Turbo Systems chip collectors to their bar feeder customers. In 2002, LNS acquired Turbo Systems. Today, chip collectors accounted for about 30 percent of global LNS sales with about 10,000 units sold annually. In 2011, LNS took another step in acquiring an Italian company, a manufacturing of air filtration systems, that could be attached to the same CNC machines using bar feeders and chip collectors. Work holding and coolant management systems were completing the strategy of a one-stop offer for CNC machine operators. ${ }^{5}$

Companies that built strong customer franchises benefited from close connections to their customers and could exert considerable market leverage due to their importance to a customers' business. Enlarging the role in its customers' business puts pressure on the supplying company, as a broader set of products, and at times even additional technologies, require more resources. At the same time, it serves as a powerful competitive deterrent.

\footnotetext{
${ }^{3}$ Adapted from Thermoplan company profile.

${ }^{4}$ See LNS company profile.

${ }^{5}$ Adapted from LNS company profile.
} 


\title{
Building a Customer Franchise Around Professional Groups
}

An alternative use of the concept of customer franchise is the building of a market position around a professional group, working either independently or as part of a company. This is particularly important when the target customers become so reliant on the supplying company's products that they can specify the supply source. Several of the researched companies have succeeded with this type of focus. Among those are Max Felchlin focusing on chocolatiers worldwide, Bachem on researchers at Pharma companies, and Medartis with its trauma implants concentrating on orthopedic surgeons.

With its couverture products, Felchlin focused the enterprise on the world's pâtissiers and chocolatiers, cementing a hold on that professional group not only by producing specialized products but also by offering a unique chocolate university where specialists from all over the world came to learn the latest techniques.

\begin{abstract}
When Max Felchlin created his honey trading business in 1908 in the town of Schwyz, there were few indications that this little trading company would someday dominate the world of pâtissiers and chocolatiers with its Couverture chocolate. The Felchlins created the foundation for a company that professional creators of pralines and other chocolate specialties would all over the world come to rely on for a key ingredient for their creations. The company grew, step by step, to encompass about 150 employees with sales estimated at CHF 60 mio, earning the highest praise for its quality and creativity. That in the land of large global chocolate companies, a small niche competitor should survive and blossom over more than 100 years deserves special attention.

Because Felchlin marketed complex products that required considerable explanation for a given selection of tastes, and how to apply them, Felchlin created Condirama in 1988, located in Schwyz and equipped to show professionals how to do it right. The school attracted 1000 to 1500 visitors annually. Swiss customers enrolled in one-day courses and did not require overnight stays. International customers, however, enrolled into one-week courses requiring a residential period. Condirama was run as a cost center. Swiss-based customers, when ordering products, received points, a form of frequent flyer miles, which could then be used to gain access to the courses at no additional cost. International customers, or users, were typically sponsored by their importers for the trip, and Felchlin covered local food and lodging costs during their stay. ${ }^{6}$
\end{abstract}

Bachem had built an entire business on the model of serving a distinct customer group in the pharmaceutical and life sciences industry. When the company started, research scientists had to create their own peptide research products. Following its own 360-degree business model, Peter Grogg, the Bachem founder, and a former lab technician, realized that a new industry could be created by stepping in and taking over this part.

Ever since its founding in 1971, Bachem had taken the lead in creating a business model that was new in the life sciences industry. Up to that time peptides had been produced internally by each company, Bachem created the market for a merchant supplier doing business with multiple life sciences customers. Over time, the peptide supply moved from being almost

\footnotetext{
${ }^{6}$ Adapted from Max Felchlin company profile.
} 
entirely captive to about 70 percent merchant based, a major change for the industry. Bachem articulated its approach as the 360-degree business model by surrounding the entire life sciences product and research process with products and services at all steps, ranging from initial research to include pre-clinical development, clinical development and the supply of peptide drugs up to commercial scale introduction.

To the research community, Bachem offered its 6,500 products, all made in-house, available from stock and to be ordered through a web shop. It represented the largest such product line in the industry. To the pre-clinical development teams of biotech and pharmaceutical companies, Bachem was able to offer custom-made peptides for the extensive panels needed in the process of further refining target compounds, involving close partnering with life sciences companies. During clinical development, when the target compound had been identified, Bachem engaged in close collaboration around the optimization process needed for development of formulations, scale-up of production and eventual validation. In the launch phase of a new drug development project, Bachem was able to act as the contract manufacturing organization by providing manufacturing up to full-scale volumes on a flexible basis, particularly important to customers in early launch when required volumes were difficult to forecast. ${ }^{7}$

Medartis, a relative newcomer to the world of orthopedic and trauma implants, focused its entire marketing on orthopedic surgeons, offering not only implants but also surgical aids, training, education, and support, thus becoming an indispensable partner to the surgeon.

The Medartis business model ran along three different but coordinated tracks involving professional training, placement of surgical sets in hospitals, and billing for the actual use of implants after surgery. Through the partnership with the International Bone Research Association (IBRA) formed in 2004 in Zurich by eighteen clinicians, a large number of educational programs and training programs were offered that treated the indications covered by Medartis implants. Offered were symposia, workshops and satellite-based events that had attracted more than 12,000 participants since 2008.

Surgical sets were placed through Medartis in cooperating hospitals, consisting of surgical instruments and implants for a large number of different surgical procedures. These sets represented a significant investment by Medartis as sets were placed on consignments and did not immediately result in direct billings. The third and final part of the business model was based upon actual use of implants and surgical instruments from sets on consignment. When kits were replenished, the used portion was billed to the hospital and represented Medartis actual sales volume. ${ }^{8}$

Companies such as Medartis, Felchlin, and Bachem, marketed directly to their respective customer franchise. However, the purchase orders, shipments, and invoice/billings were made to the companies that employed these professionals. Having direct access to professionals and being able to explain their products to the using professional, enhanced the hold these companies could exert on those professional users. It promoted customer loyalty and preference over the long term. An expanded service offering, going beyond physical products, was also found to be a prerequisite to make this work. Explains Willi Miesch, CEO of Medartis, It is best

\footnotetext{
${ }^{7}$ Adapted from Bachem company profile.

${ }^{8}$ Adapted from Medartis company profile.
} 
to control selling, education and training to direct the business. What is essential is exercise influence control. ${ }^{9}$

\section{Adopting a Solution-Based Customer Franchise}

In the previous focus strategies, the companies discussed brought products, or technologies, to a given industry sector or customer groups. Some companies have, as an expansion and partly as a defensive strategy, developed entire systems, moving from product-based offerings to a systems business. The firms enhanced their core product with other offerings to combine them into a complete system while always maintaining the same customer focus.

Lantal, the specialty textile manufacturer with a heavy emphasis on the transportation sector, is a case in point where the systems focus was implemented step-bystep to move from textiles to airplane seat covers to other parts of the cabin interior.

The more customers Lantal was able to win, the more likely some of these customers were to ask whether it could also offer the right carpet, as the quality of its core products was very good. When the opportunity emerged to take over a carpet weaving mill in nearby Melchnau, which had run into difficulties, owner Urs Baumann decided to buy it in 1985. From that year on, the company could offer not only seat covers but also carpets from the same source.

It is important to know that a carpet machine could only be used for the production of carpets and not for other fabrics. For airplane seat covers, flat weaving was used, which was completely different from carpet weaving or plush/velvet weaving applying different technologies, employing different machines and utilizing different processes. In addition, Lantal produced handmade carpets for very special purpose applications. Overall, Lantal became the only company in the world which was able to offer products based on four different production technologies from one source: carpets, velvet, flat woven and handmade carpets. Thus, Lantal was able to completely plan the entire interior and to cover every product within a cabin while its competitors could only offer individual products and had to cooperate with other suppliers to offer broader solutions. ${ }^{10}$

To qualify as a complete solution supplier, Lantal had to expand beyond its traditional weaving technology by adding new capabilities, either through acquisition or expansion, in an industry where suppliers usually concentrated on one technology only. This added complexity to its business, which was partly offset by training its weaving staff on multiple machines to be able to reassign them as demand required. Such manning flexibility could only be achieved with a highly qualified staff.

\footnotetext{
${ }^{9}$ ibid.

${ }^{10}$ Adapted from Lantal company profile.
} 


\section{Employing a System-Centered Approach}

Different pathways were chosen by Komax and Oetiker, two companies with a concentration on the automotive sector. Komax, already in the cabling equipment business with cabling companies as its main customers, added downstream equipment with which customers could supplement their cable harness producing lines, thus offering a complete system solution.

The majority of Komax customers were wire harness manufacturers who processed individual wires, still predominately by hand, into a wire harness that was delivered to the automotive companies (OEMs). Komax offered these companies a wide range of solutions and systems for automated and more efficient processing of wires, as well as for taping and testing the harness. Komax equipment was used in the cutting rooms, at the pre-assembly stage, and during taping and testing. Komax also supported its customers along the entire value chain, from planning to delivery, with the Komax MES. This software automated planning, controlling, monitoring, and analysis of all resources and production processes. This had the effect of optimally deploying machines, materials, and employees with the goal to complete deliveries in line with deadlines and at the specified quality level. ${ }^{11}$

At Oetiker, the company was producing the clamps used in large numbers by automotive OEMs and Tier One assemblers. While Oetiker produced these clamps in its own plants located around the world, the company began to acquire other firms that offered clamp installing tools.

Since Oetiker produced clamps needed to be assembled in large quantities into different parts by automotive sub-assemblers, the company used acquisitions to bring together a set of tools and equipment that could be used for the assembly of clamps. For this purpose, Oetiker acquired Allert in 1997, since 1980 active in fastening, for the automotive sector, as well as supplying hinged steel belt conveyors. Allert continued to operate under its own brand name and was kept as a separate legal entity in the form of a fully owned subsidiary.

Levi Peterson, a Swedish company active globally in engineered fastening devices specialized for commercial vehicles, was acquired in 2014 and has operated since then as Oetiker Sweden AB, combining sales and production operations on the same site. Also, in 2014, Oetiker acquired Rostra Tool Company, based in Connecticut, US. Rostra, with a 150-year history, marketed its flagship brand 'Sargent Quality Tools', hand tools for crimping, pressing, cutting and stripping to wholesale distributors and other industrial users. For Oetiker, the hand tool lines added to its system approach serving clients not only with connecting solutions but also the required installation tools. Rostra also held a strong position in the PEX plumbing connection market, another important strategic objective for Oetiker. The company was now operating as Oetiker Tools, but was keeping the Sargent brand names for specific products. ${ }^{12}$

Becoming a system supplier brings new complexities. Whereas a product supplier can exploit a single technology into multiple application markets, the system supplier is confronted with leveraging additional technologies, or products, into a single

\footnotetext{
${ }^{11}$ Adapted from Komax company profile.

${ }^{12}$ Adapted from Oetiker company profile.
} 
user segment. This requires a focus on one, or few, customer groups, as systems tend to be narrowly engineered from an application point of view. Furthermore, the added business expansion favors larger firms, usually from CHF 100 million and more.

\section{Consumer Franchise Focus}

As mentioned previously, the building of a consumer brand franchise in a businessto-business (B2B) environment was a more commonly known concept of franchise building. The documented firms who were mostly B2C did engage in such brand marketing activities, and those firms could be said to have been successful at building such franchises. We describe the brand franchise building activities in Chap. 13 by putting the spotlight on the global branders Ricola, Jura, Caran d'Ache, and Kuhn Rikon.

Contrary to the B2B customer franchise builders, the consumer franchise builders target a broader sector of the market. To make this form of focus work required a single brand name and brand image building that connected with the target consumer segment.

Caran d'Ache and Felco covered both professional users and individual consumers. For Caran d'Ache, the individual consumers represented the larger group, whereas for Felco the home users, or do-it-yourself (DIY) gardeners, were a smaller group compared to the professional wine growers. That means that those two companies had to manage both forms of franchise building. Among the research group, however, these were exceptions.

Plaston also marketed to both industrial customers for the tool storage boxes and individual household customers for its air washing products. Using a separate brand name, Boneco, made Plaston a dual brand company.

The two previous chapters have outlined the many different ways SME management chose to focus their businesses. This description might have created an impression that company managers select their focus in the form of a deliberate process, getting to their desired position in a single step. The next chapter will show that for many SMEs, the focus is a journey, not the result of a singular decision. How such a focus journey is navigated has a lot to do with their eventual success.

Open Access This chapter is licensed under the terms of the Creative Commons Attribution 4.0 International License (http://creativecommons.org/licenses/by/4.0/), which permits use, sharing, adaptation, distribution and reproduction in any medium or format, as long as you give appropriate credit to the original author(s) and the source, provide a link to the Creative Commons license and indicate if changes were made.

The images or other third party material in this chapter are included in the chapter's Creative Commons license, unless indicated otherwise in a credit line to the material. If material is not included in the chapter's Creative Commons license and your intended use is not permitted by statutory regulation or exceeds the permitted use, you will need to obtain permission directly from the copyright holder. 